\title{
Peristomal plate cut mold: possibilities for applying new products
}

\section{Molde de recorte da placa periestomal: possibilidades de aplicação de novos produtos}

\section{Molde de recorte de la placa periestomal: posibilidades de aplicación de nuevos productos}

\author{
Claudini Lacerda Marques de Freitas Sichieri', Diba Maria Sebba Tosta Souza², \\ Ana Beatriz Alkmim Teixeira-Loyola², Manoel Araújo Teixeira ${ }^{2}$
}

ORCID IDS

Sichieri CLMF (iD https://orcid.org/0000-0001-5138-4743 Souza DMST (iD https://orcid.org/0000-0002-4743-2455 Teixeira-Loyola ABA (iD https://orcid.org/0000-0002-9089-7012 Teixeira MA (D) https://orcid.org/0000-0002-8088-2351

\section{COMO CITAR}

Sichieri CLMF, Souza DMST, Teixeira-Loyola ABA, Teixeira MA Peristomal plate cut mold: possibilities for applying new products. ESTIMA, Braz. J. Enterostomal Ther., 17: e1019. https://doi. org/10.30886/estima.v17.678_IN

\begin{abstract}
Introduction: peristomal dermatitis can be caused by leakage between adhesive plate and skin. Objective: to describe the peristomal plate cut mold (PPCM) for simultaneous evaluation of new products for the treatment of dermatitis. Methods: experience report about creation of a cut model, with sufficient size and width to expose part of the skin with dermatitis, to apply another product. The trapezoidal cut, according to positions 3, 6, 9 or 12 hours, corresponding to one of the quadrants, it was performed on the plate of carboxymethylcellulose, pectin, and gelatine coupled to the stoma bag. The entire part of the plate adhered to the skin was adapted to the control product. In the photographic analysis, CoreIDRAW 19.0 was used. The lesions were measured in pixels. Result: the cut did not interfere with the adhesion of two parts device board, it made possible the simultaneous application and testing of a new product and the comparison of the healing with the plate. Conclusion: the PPCM is a new strategy for studies of the application of other products for peristomal dermatitis simultaneously in the same patient and demonstrates positive results in its use.
\end{abstract}

DESCRIPTORS: Healing; Dermatitis; Surgical Stoma; Computer Assisted Image Processing; Technology; Photography; Stomatherapy

\footnotetext{
1.Prefeitura Municipal de Divinópolis - Secretaria Municipal de Saúde - Diretoria de Urgência e Emergência - Divinópolis/MG - Brazil. 2.Universidade do Vale do Sapucaí - Mestrado Profissional em Ciências Aplicadas à Saúde - Pouso Alegre/MG - Brazil.

*Correspondence author: souzadiba@gmail.com

Received: 14 Dec 2018 | Accepted: 02 May 2019
} 


\section{RESUMO}

Introdução: Dermatite periestomal pode ser causada por vazamentos entre placa adesiva e pele. Objetivo: Descrever o molde de recorte da placa periestomal (MRPP) para avaliação simultânea de novos produtos para tratamento de dermatite. Métodos: Relato de experiência sobre a criação de modelo de recorte, com tamanho e largura suficientes para exposição de parte da pele com dermatite, para aplicação de outro produto. O recorte, em forma trapezoidal e, em acordo com as posições 3, 6, 9 ou 12 horas, correspondendo a um dos quadrantes, foi realizado na placa de carboximetilcelulose, pectina e gelatina acoplada à bolsa para estomas. A parte íntegra da placa aderida à pele adequou-se ao produto-controle. Na análise fotográfica, utilizou-se CorelDRAW 19.0. As lesões foram mensuradas em pixels. Resultado: O recorte não interferiu na aderência da placa do dispositivo de duas peças, possibilitou a aplicação e teste simultâneo de novo produto e a comparação da cicatrização com a placa. Conclusão: O MRPP é uma nova estratégia para estudos da aplicação de outros produtos para dermatite periestomal de forma simultânea no mesmo paciente e demonstra resultados positivos em seu emprego.

DESCRITORES: Cicatrização; Dermatite; Estoma Cirúrgico; Processamento de Imagem Assistida por Computador; Tecnologia; Fotografia; Estomaterapia.

\section{RESUMEN}

Introducción: Dermatitis perormomal puede ser causada por fugas entre placa adhesiva y piel. Objetivo: Describir el molde de recorte de la placa periestomal (MRPP) para la evaluación simultánea de nuevos productos para el tratamiento de dermatitis. Métodos: Relato de experiencia sobre la creación de modelo de recorte, con tamaño y anchura suficientes para la exposición de parte de la piel con dermatitis, para aplicación de otro producto. El recorte, en forma trapezoidal y, de acuerdo con las posiciones 3, 6, 9 o 12 horas, correspondiendo a uno de los cuadrantes, fue realizado en la placa de carboximetilcelulosa, pectina y gelatina acoplada a la bolsa para estomas. La parte íntegra de la placa adherida a la piel se adecuó al producto-control. En el análisis fotográfico, se utilizó CorelDRAW 19.0. Las lesiones se midieron en píxeles. Resultado: El recorte no interfirió en la adherencia de la placa del dispositivo de dos piezas, posibilitó la aplicación y prueba simultánea de nuevo producto y la comparación de la cicatrización con la placa. Conclusión: El MRPP es una nueva estrategia para estudios de aplicación de otros productos para dermatitis periestomal de forma simultánea en el mismo paciente y demuestra resultados positivos en su empleo.

DESCRIPTORES: Cicatrización; Dermatitis; Estoma Quirúrgicos; Procesamiento de imágenes; Asistida por ordenador; Tecnología; Fotografía.

\section{INTRODUCTION}

Among the main causes related to the confection of stomas to the adult and elderly population in Brazil are neoplasias, mainly colorectal cancer, whose estimates for 2018 presented it as the third most incident for men, with 17.380 new cases, and the second for women, with $18.980^{1}$.

In addition to colorectal and bladder cancers, most often, the stomas are linked to chronic intestinal and urinary diseases, inflammatory diseases such as Crohn's disease, ulcerative colitis and diverticulitis, and the treatment of congenital diseases and abdominal trauma ${ }^{2}$.

The confection of a stoma is considered a common procedure and is performed by several surgical specialties. Although commonly processed, it presents mostly underestimated complications ${ }^{3}$. There are advances in surgical techniques and improvement of practices and products, however, $70 \%$ of people with stomas presented complications, with peristomal dermatitis being the most prevalent and its causes varied ${ }^{45}$.

The most common factor of this disease is the inadequate adherence of the collector equipment to the abdominal wall, causing leakage of effluent on the peristomal skin. The reasons that contribute to its development are associated, for the most part, with the poor location of the stoma or even with the mistaken choice of the collector system ${ }^{6}$.

Thus, preventive and treatment measures are necessary, among them the removal of the root cause, the incentive to self-care of the skin and the correct and indicated the application of covers for the reestablishment of peristomal skin $^{7}$. The loss of control of eliminations in people with stoma forces them to use collector devices, which are several, but all have a protective skin plate and a bag to store the effluent. Some devices are composed of two parts (plate and bag) and others of a single part in which the bag is inseparable from the plate ${ }^{8}$. 
In spite of the technology applied in the manufacture of such devices, as it is adherent products to the skin, leakages can occur between the adhesive plate and the skin, as well as between the plate and the bag (in the case of a two parts device) what, for prolonged periods, due to the effluent characteristic, can damage the peristomal skin ${ }^{8}$.

The covering is considered any material, substance or product that is applied on a wound, forming a physical barrier with protection and cellular regeneration capacity. Effective treatment of any lesion implies, among other precautions, the choice of the most appropriate type of coverage for each specific type of wound, in different clinical and surgical situations ${ }^{9}$. The coverages can be classified as primary, applied directly to the lesion, and secondary, applied over primary coverage ${ }^{10}$.

Although the tissue repair process is systemic, in order to be effective, it is necessary to favor the local conditions of the lesion with appropriate topical treatment. In this sense, in the last decades, there was a true technological revolution based on scientific researches that evaluated biomaterials and diverse products for the treatment of wounds ${ }^{7}$.

Even with investment in research focused on the healing field and the belief that there are too many products on the market, mostly with technologies patented by multinationals, perfecting such resources is essential not only to make these resources cheaper and more accessible to the public. as many people as possible, but also to enable the use of raw materials found in all regions of Brazil ${ }^{11}$.

With the increasing necessity to validate therapeutic efficacy, objective measurements are paramount to current health care ${ }^{12}$. The rapid change in the field of health sciences makes the initial training of professionals quickly obsolete. New equipment and technologies, as well as procedures and new practices, are areas that require updating of knowledge ${ }^{13}$.

In this context, the cut in the plate of the collector bag allows the application of new products in the patient with peristomal dermatitis, evaluating different products for the treatment of this condition.

\section{OBJECTIVE}

The present study aims to describe the peristomal plate cut mold (PPCM) for the simultaneous evaluation of new products for the treatment of dermatitis.

\section{METHODS}

Experience report approved by the ethics committee (CAAE 69729217.2.0000.5102 under opinion $n^{\circ}$. $064826 / 2017)$ on the creation of a model of cut with sufficient size and width to expose part of the skin with dermatitis to the application of another product. This cut mold was performed in trapezoidal form and, according to positions 3, 6, 9 or 12 hours, corresponding to one of the quadrants. It was realized on the carboxymethylcellulose plate, pectin and gelatine coupled to the stoma bag.

The PPCM was applied in two people with a colostomy who accepted and signed the Free and Informed Consent Term.

The cut leaves part of the exposed peristomal skin and allows the application of a product and the observation of the possible interference of the cut in the adhesion of the plate and in the evaluation of the scars properties of two products. The procedures to perform the mold were performed in four steps:

1. In the peristomal skin with the presence of dermatitis, the cleaning was realized with $0.9 \%$ physiological solution in warm temperature (Fig. 1a).

2. The cut on the carboxymethylcellulose, gelatine and pectin plate, the peristomal skin into which the new product was applied was exposed. The area of the cut corresponded to the study area in order to evaluate healing. The whole part (without the cut) corresponded to the control area (Fig. 1b).

3. The plate with the cut area (study) and the area of the plate (control) was fixed to the skin (Fig. 1b).

4. After the fixation in the area of the cut, a new product was applied (study) (Fig. 1c).

The percentage calculation was realized in four stages:

1. The total area of the lesion in pixels was calculated using the CorelDRAW program.

2. The areas of application of the product study and application of the control product, separately, in pixels, were calculated.

3. The values of the areas of the study group and the control group were converted into percentages of areas.

4. The percentage difference of the initial areas (photographic record of day 0 ) and final (photographic record of day 8) of each location was calculated (Fig. 2). 
The pictures were made at a $90^{\circ}$ angle at a distance of $25 \mathrm{~cm}$. After the pixel measurements based on Tacani et al. ${ }^{14}$ to evaluate healing, the pixel units were converted into percentages by the Microsoft Excel 2013 program. The final result of the study and control areas was obtained separately.

The results of the photographic records used in the analysis were realized on days 0 and 8 of the areas of application of the study product and control product.

The purse size measurement model was evaluated in two participants with a colostomy at the Divinopolis Medical Specialties Center in the state of Minas Gerais, Brazil, using a two parts collector device that presented peristomal dermatitis with a partial thickness lesion.

The product used was a herbal gel that is in the process of being registered at the National Institute of Industrial Property
(NIIP), which was compared to the base of the collector bag - a conventional product of carboxymethylcellulose, gelatine, and pectin - that adheres to the skin. The photographic records analyzed were done on days 0 and 8 of the research. The cut was made on the skin barrier board. This protective barrier is also the same fitting plate of the collector bag of the device.

\section{RESULTS}

Table 1 shows the results of the percentage analysis of the lesion reduction in the study and control areas of participants 1 and 2 and in Fig. 3 the healing evolution of both areas, study and control was reported by participant 2 .

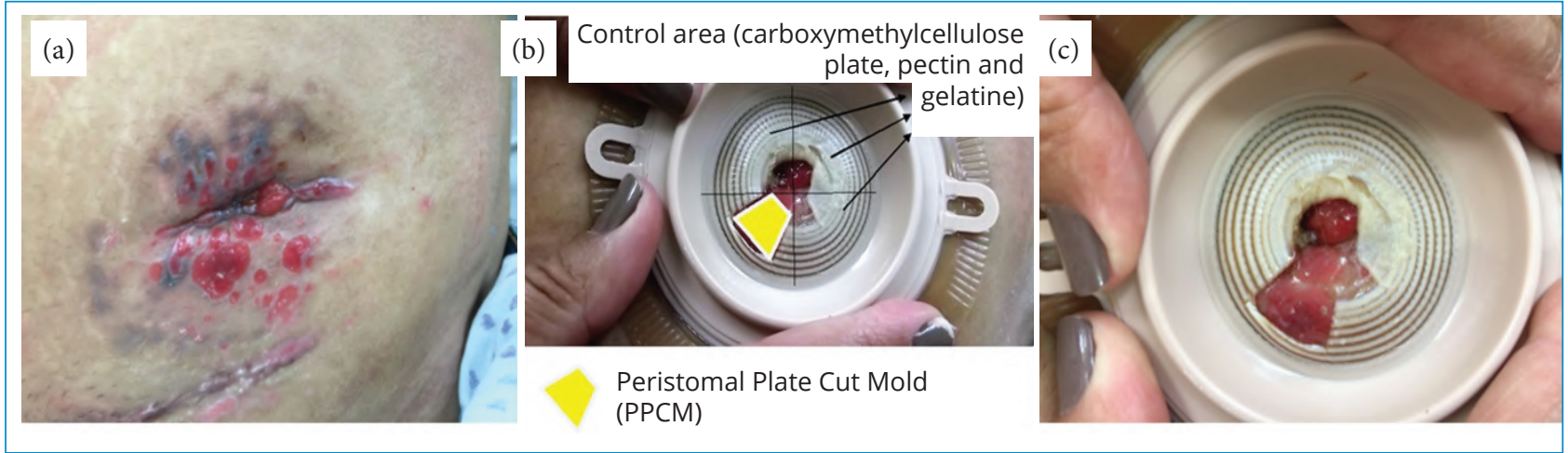

Figure 1. (a) Peristaltic dermatitis after cleaning, (b) Second and third stages of the PPCM, (c) Fourth stage of PPCM demonstrating the applied product,Divinopolis, state of Minas Gerais, Brazil.
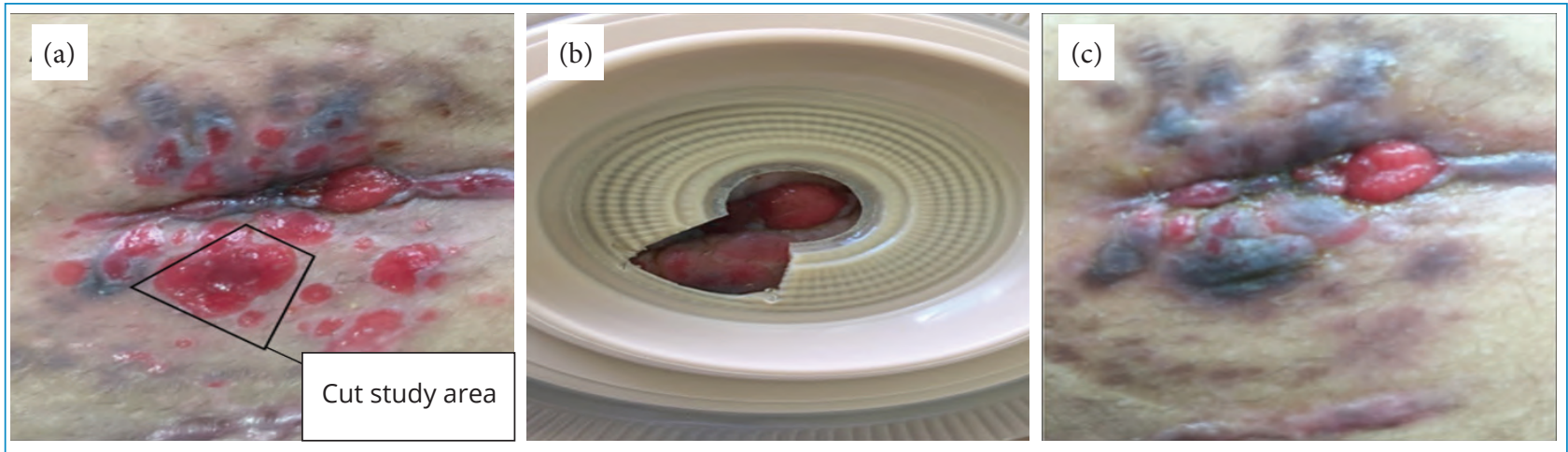

Figure 2. (a) Cut study area, (b) Participant 1 on day 0, (c) Participant 1 on day 8, Divinopolis, state of Minas Gerais, Brazil.

Table 1. Description of the percentage analysis of lesion reduction in study and control areas of participants 1 and 2 with a colostomy. Divinopolis, state of Minas Gerais, Brazil.

\begin{tabular}{|c|c|c|c|c|}
\hline \multirow{2}{*}{ Participant } & \multirow{2}{*}{ Description } & \multirow{2}{*}{$\begin{array}{c}\text { Day } 0 \\
\text { Initial area }\end{array}$} & \multicolumn{2}{|c|}{ Day 8} \\
\hline & & & Final area & Reduction \\
\hline 1 & Study area & 100,0 & 12,1 & 87,8 \\
\hline 1 & Control area & 100,0 & 11,4 & 88,5 \\
\hline 2 & Study area & 100,0 & 0,0 & 100,0 \\
\hline 2 & Control area & 100,0 & 0,0 & 100,0 \\
\hline
\end{tabular}




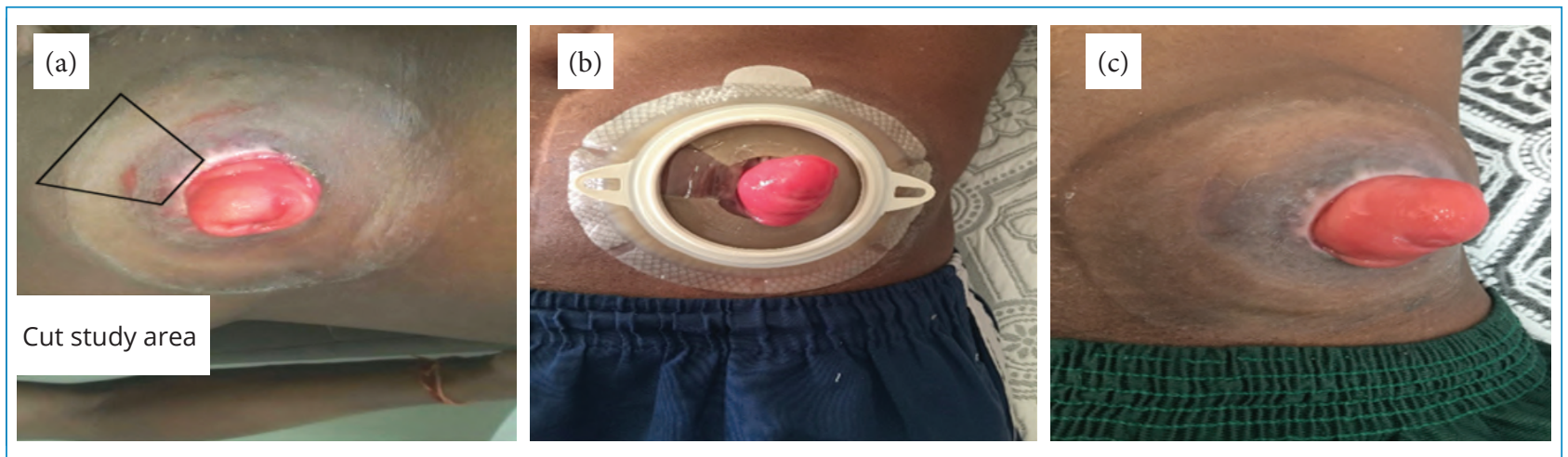

Figure 3. (a) Cut study area, (b) Participant 2 on day 0, (c) Participant 2 on day 8, Divinopolis, state of Minas Gerais, Brazil.

\section{DISCUSSION}

The evaluation of changes in wound size over time is often considered a primary indicator of successful treatment. The high degree of accuracy and reproducibility in measurement techniques is highly desirable in clinical settings and is extremely important in research studies whose variation in wound size is a primary outcome15. There is no standard protocol for assessing wound size and monitoring the healing of peristomal dermatitis. In the present study, a mold with a cut was developed that favors the evaluation of a site where it was not possible to analyze the healing process of these lesions since the stoma carrier could not be left without the collector bag.

In the photographic analysis of the cut mold of the collector bag, the picture was relevant when the pixel units were converted in percentage by the Microsoft Excel 2013 program, reaching the final percentage result of study and control areas, separately. This strategy confirms that the wound image can be obtained through digital or manual photographic cameras and has the advantage of providing a clear sample of the appearance of the wound, as it suggests its size when a ruler is used next to the lesion and serves as a parameter for evaluations. However, it does not provide precision regarding depth and other aspects of the lesion ${ }^{16}$.

The same authors emphasize the importance of certain diligence, such as keeping the same distance and angle of the lesion when photographing it, labeling it with date and place, requesting written approval to the client or guardian to photograph, or explaining its objective and guaranteeing the continuity of treatment, even if it no longer wants to be photographed. Photographic documentation should be done in color and with intervals of days so that changes can be evaluated over time. In this way, patients and relatives have the opportunity to follow the evolution of healing through the pictures, which serve as an incentive and stimulus to the treatment. These details were observed during the capture of the images of the mold of the collector bag cut and during the evaluation of this new model in order to investigate the peristomal dermatitis ${ }^{16}$.

In a literature review, it was found that peristomal dermatitis has been studied in an incipient way because it is considered "simple" and its classification is based on those established by other segments of the treatment of skin lesions. Classifications of peristomal dermatitis are generally proposed as mild, moderate and severe (severe or intense $)^{17}$. In this investigation, to evaluate the model of a PPCM, we evaluated people with mild to moderate dermatitis and using a two parts bag, whose base of the device was resistant to the cut and application of a new product, proving that the mold did not alter the conventional use of the bag.

In a recent study, the authors identified international instruments constructed and developed to perform the classification of peristomal skin lesions, but few with properties of measures tested and, in a smaller number, studies of cultural adaptation and validation for translations and application in other languages ${ }^{4}$. The importance of the testing of these properties and the validation, translation and cross-cultural adaptation of these new instruments, which early detect the risk factors and prevent these peristomial affections from worsening. This fact corroborates the present study in 
which dermatitis was initially identified and presented superficially.

The most common causes of dermatitis have been described as irritative or triggered by inflammatory processes of the peristaltic skin in contact with the eliminations and maximized by products and traumas, factors that change the $\mathrm{pH}$ of the skin, such as allergies that can be caused by the device used (plate resin area, for example), trauma involving abrasive cleaning techniques, as well as inadequate removal of devices and factors related to surgical technique, comorbidities, age, among others ${ }^{18}$.

In this study, participants were affected by one or more complications, especially late complications, such as dermatitis occurring more than 15 days after surgery. It also presented alterations of the skin, and one presented flushing and heat and both presented pain and superficial lesion, signs, and symptoms characteristic of peristomal dermatitis present in the skin of the study and control area, guaranteeing uniformity to the research. It is worth noting that both areas, study, and control, presented total healing, without interference between them and equating a conventional product established with the new product.

During the evaluation of the PPCM method, there was no interference in the adhesion of the control group. Even in a hostile environment, with variations in moisture and acidity, the study product remained attached to the skin for more than 40 hours, as did the control product.
Thus, it is believed that there is a necessity for clinical studies with a greater number of participants to concretize the use of this innovative resource and to implement new products for the healing and adherence of the peristaltic area.

\section{CONCLUSION}

The PPCM method was created with possibilities for the evaluation of two products simultaneously to the treatment of peristaltic dermatitis with partial thickness lesions. In people with colostomy and peristomal dermatitis, it has been demonstrated that the adhesion of the conventional plate does not change, allows the application of another product in the study area and maintains the conventional product in the control area in the same person. PPCM is a new strategy for studies of different products at the same time in the same patient and indicates positive results in its use.

\section{AUTHOR'S CONTRIBUTION}

Conceptualization, Sichieri CLMF and Souza DMST; Methodology, Sichieri CLMF; Souza DMST; Teixeira-Loyola $\mathrm{ABA}$ and Teixeira MA; Investigation, Sichieri CLMF and Souza DMST; Writing - First version, Sichieri CLMF; Souza DMST; Teixeira-Loyola ABA and Teixeira MA; Writing - Review \& Editing, Sichieri CLMF and Souza DMST; Resources, Sichieri CLMF and Souza DMST; Supervision, Souza DMST.

\section{REFERENCES}

1. Instituto Nacional de Câncer. Causas e prevenções. Estatística de câncer [Internet]. Rio de Janeiro: INCA; 2018 [cited 10 May 2019]. Available at: https://www.inca.gov.br/ numeros-de-cancer

2. Silva AC, Silva GNS, Cunha RR. Caracterização de pessoas estomizadas atendidas em consulta de enfermagem do serviço de estomoterapia do município de Belém-PA. ESTIMA, Braz J Enterostomal Ther. 2012;10(1):20-7.

3. Santos $\mathrm{CHM}$ dos, Bezerra MM, Bezerra FMM, Paraguassú BR. Perfil do paciente ostomizado e complicações relacionadas ao estoma. Rev Bras Coloproct. 2007;27(1):169. https://doi.org/10.1590/S0101-98802007000100002

4. Nunes MLG, Santos VLCG. Instrumentos de avaliação das complicações da pele periestoma: revisão integrativa. Aquichan. 2018;18(2):477-91. https://doi.org/10.5294/aqui.2018.18.4.9
5. Paula PR, Matos D. Complicações precoces e tardias nas estomias intestinais e pele periestomia. In: Santos VLCG, Cesaretti IUR, editores. Assistência em estomaterapia: cuidando de pessoas com estomias. São Paulo: Atheneu; 2015. p. 311-9.

6. Asociación Mexicana de Cirugía General. Guía de pratica clínica basada en evidencia científica para el marcaje y manejo integral de personas adultas con estomas de eliminación [Internet]. México: AMCG; 2011.

7. Diniz RV, Anselmo MN, Soares RAS, Santos IBC, Oliveira MJGS. Problema de pele em paciente estomizada: relato de caso. R Bras Cai Saúde. 2013;17(4):371-6. https://doi. org/10.4034/RBCS.2013.17.04.08

8. Collet JA, Silva FP, Aimone JFL. Bolsas coletoras utilizadas por estomizados: uma análise tridimensional. Design Tecnol. 2016;11:1-10. https://doi.org/10183/151143 
9. Galvão MTG, Alexandre HO, Dantas PB, Lima ICV de, Lopes EM. Uso da fotografia no processo do cuidar: tendências das ações de enfermagem. Cienc Enferm 2013;19(3):31-9. https://doi.org/10.4067/S0717-95532013000300004

10. Blanes L. Curativos. In: Ferreira LM. Guia de cirurgia plástica/ coordenação das seções. Barueri: Manole; 2007. p. 83-89.

11. Mandelbaum SH, Di Santis EP, Mandelbaum MHS. Cicatrização: conceitos atuais e recursos auxiliares - Parte I. An Bras Dermatol. 2003;78(4):393-410. https://doi. org/10.1590/S0365-05962003000400002

12. Carvalho RM de, Perez MCJ, Miranda Júnior F. Volúmetro com câmaras: apresentação de um protótipo de dimensões reduzidas desenvolvido para a avaliação objetiva do volume de mão. J Vasc Bras. 2010;9(2):76-80. https://doi. org/10.1590/S1677-54492010000200011

13. Moran JM, Lavado-Garcia JM, Pedrera-Zamorano JD. Métodos de enfermagem para a medição da composição corporal. Rev Latino-Am Enfermagem. 2011;19(4):1033-8. https://doi.org/10.1590/S0104-11692011000400024
14. Tacani PM, Toguchi PAPM, Machado AFP, Tacani RE, Freitas JOG. Prevalência e tratamento fisioterapêutico de deiscências da ferida operatória após cirurgias plásticas: análise retrospectiva. R Bras Ci Saúde. 2014;12(39):28-34. https://doi.org/10.13037/rbcs.vol12n39.2110

15. Haghpanah S, Bogie K, Wang X, Banks PG, Ho CH. Reliability of electronic versus manual wound measurement techniques. Arch Phy Me Rehabil. 2006;87(10):1396-1402. https://doi. org/10.1016/j.apmr.2006.06.014

16. Oliveira BGRB, Castro JBA, Andrade NC. Técnicas utilizadas na aferição de feridas e avaliação do processo cicatricial. Saúde Coletiva 2005;2(6):57-62.

17. Bosio G, Pisani F, Lucibello L, Fonti A, Scrocca A, Morandell C, et al. A proposal for classifying peristomal skin disorders: results of a multicenter observational study. Ostomy Wound Manage. 2007;53(9):38-43.

18. Santos VLC de G. Como eu trato as dermatites periestoma. Rev Esc Enferm USP. 1994;28(I):67-71. https://doi. org/10.1590/0080-6234199402800100067 